\title{
Use of subcutaneous abdominal fat biopsy specimen for detailed typing of amyloid fibril protein-AL by amino acid sequence analysis
}

\author{
P WESTERMARK, L BENSON, * JESSIE JUUL, $†$ K SLETTEN† \\ From the Department of Pathology, University of Linköping, Linköping, the *Department of Internal Medicine, \\ University of Uppsala, Sweden, and the †Department of Biochemistry, University of Oslo, Oslo, Norway
}

SUMMARY A simple technique for the purification of amyloid fibril proteins from patients with systemic amyloidosis was used on a 45 year old woman. The method is based on the use of a surgical subcutaneous fat tissue biopsy specimen which was used for the characterisation of the amyloid as a $\kappa$ I AL-protein by amino acid sequence analysis. The method permits the exact typing of amyloid in many patients with systemic amyloidosis, which, until now has been almost exclusively confined to necropsy tissue.

Amyloid is the pathological deposition of protein fibrils with characteristic appearance and properties. The fibrils are polymers of small proteins. Several different proteins can give rise to amyloid fibrils, and different subunit proteins are characteristic of each clinical syndrome. Thus the amyloid protein deposited in plasma cell dyscrasias is derived from monoclonal immunoglobulin light chains ${ }^{1}$ while protein AA, derived from the acute phase reactant serum AA protein, occurs in secondary systemic amyloidosis. ${ }^{2}$ Transthyretin (prealbumin) forms fibrils in familial amyloidoses and in senile systemic amyloidosis. ${ }^{3-5}$

In the different systemic types of amyloidosis deposits occur in most organs. The clinical symptoms vary greatly not only between the forms but also between patients. The diagnosis is therefore often difficult. For diagnosis, microscopical examination of a biopsy specimen is still necessary. Because amyloid deposits are so widely spread, it is usually not necessary to take biopsy specimens from organ systems giving rise to clinical symptoms. We showed that a fine needle biopsy specimen from the subcutaneous fat tissue, spread on a glass slide, and studied in polarised light after staining with Congo red, usually contains enough amyloid for diagnosis in primary (AL) and secondary systemic amyloidosis. ${ }^{67}$ The value of the method has been verified by other groups ${ }^{8-11}$ and the method has also turned out to be useful in familial amyloidosis as well. ${ }^{10}$
Subcutaneous fat tissue can also be used for the typing of systemic amyloidosis in patients. ${ }^{12}$ For that, we designed a method by which a piece of subcutaneous fat is removed surgically and extracted. The dissolved amyloid fibril proteins are then studied by double immunodiffusion. ${ }^{13}$ With this method it is usually possible to determine whether the amyloid is AA, AL, or prealbumin. ${ }^{13}$

\section{Material and methods}

A 45 year old woman, originally coming from a region with familial amyloidosis, had had recurrent pneumonias for one year (case 1). Three months before the biopsy specimen was taken, she developed nephrotic syndrome. There were no signs of myeloma. A subcutaneous biopsy specimen with a volume of about $1 \mathrm{~cm}^{3}$ was taken from the anterior part of the abdomen, put into $0 \cdot 15 \mathrm{M}$ sodium chloride and sent to the laboratory.

A smear from a small piece of the biopsy specimen exhibited large amounts of amyloid around fat cells. ${ }^{6}$ The rest of the tissue was stirred in $0.15 \mathrm{M}$ sodium chloride overnight at $+4^{\circ} \mathrm{C}$, rinsed in distilled water, defatted with acetone and air-dried. Sodium dodecyl sulphate-polyacrylamide gel electrophoresis (SDSPAGE) was performed as described previously. ${ }^{14}$

PURIFICATION OF AMYLOID FIBRIL PROTEIN The dry material was treated $(5 \mathrm{mg} / \mathrm{ml})$ with $6 \mathrm{M}$ guanidine-hydrochloric acid in 0.1 Tris- $\mathrm{HCl}, \mathrm{pH} \mathrm{8.0,}$ containing $0.1 \mathrm{M}$ dithiothreitol and $0.2 \mathrm{M}$ edetic acid 


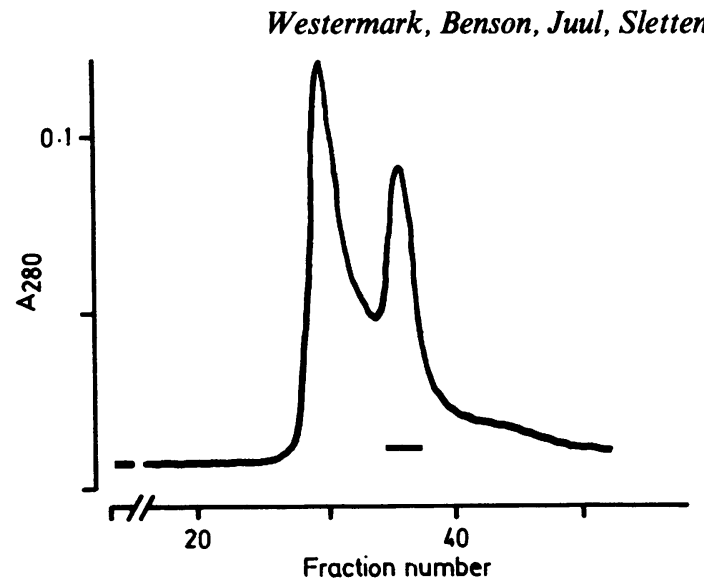

Fig 1 Gel filtration of extract of defatted abdominal fat tissue of case 1. Fractions, indicated by bar were used for further purification by high pressure liquid chromatography and amino acid sequence analysis.

differed from the $\kappa$ I prototype only in position 4 (valine for methionine) (fig 2). In material from one peak, besides the amyloid protein sequence, there were shadow sequences of hemoglobin $\alpha$ and $\beta$ chains (data not shown).

\section{Discussion}

pressure liquid chromatography was dried, redissolved in $30 \%$ formic acid, and applied to a $477 \mathrm{~A}$ Protein Sequencer (Applied Biosystems, Foster City, California). The phenylthiohydantoin-derivatised amino acid residues were determined on line with the aid of an Applied Biosystems 120 phenylthiohydantoin analyzer.

\section{Results}

During immunodiffusion of the extract from abdominal fat tissue a reaction appeared only with antiserum to the amyloid fibril protein Es $305,{ }^{15}$ which is of $\kappa$ immunoglobulin light chain origin. No precipitation lines were obtained with antisera to protein AA, to AL proteins of $\lambda$ type, or to an amyloid fibril protein of transthyretin type.

SDS-PAGE of the fat tissue extract exhibited a strong band with an apparent molecular mass of about 16 kilodaltons and several more slowly migrating weak bands. Gel filtration of the extracted material showed only one retarded peak (fig 1). When this peak material was subjected to reversed phase high pressure liquid chromatography, a group of closely eluted peaks occurred. The two major peaks were analysed by amino acid sequence for 21 and 29 cycles, respectively. In both instances a sequence, characteristic of a $\kappa \mathrm{I}$ immunoglobulin light chain was obtained and this
The fine needle biopsy specimen of abdominal subcutaneous fat was developed as an easy and safe method for the diagnosis of systemic amyloidosis. ${ }^{6}$ It has now been used for 15 years and its usefulness has been verified in several studies. ${ }^{8-11}$ When properly performed it is as reliable as a rectal biopsy specimen.

Usually it is possible to determine the type of amyloidosis a patient has from the clinical data. Occasionally, however, the type of amyloidosis is uncertain and an analysis of the amyloid fibrils is needed. Immunohistochemical methods have been applied to sections of paraffin wax embedded biopsy specimens which permitted typing in many cases. ${ }^{16-19}$

\begin{tabular}{l}
$\begin{array}{l}\text { AL-EN } \\
\text { Roy }\end{array}$ \\
(Asp)-Ile-Gin-Val-Thr-GIn-Ser-Pro-Ser-Ser- \\
Met \\
$\begin{array}{l}\text { AL-EN } \\
\text { Roy }\end{array}$ \\
$\begin{array}{l}\text { AL-EN-Ser-Ala-Ser-Val-Gly-Asp-Arg-Val-Thr- } \\
\text { study) }\end{array}$ \\
$\begin{array}{l}20 \\
\text { Roy }\end{array}$ \\
\hline
\end{tabular}

Fig $2 N$-terminal amino acid sequence of amyloid protein $A L-E N$ (case 1). The sequence is nearly identical with that of the $\kappa$ I immunoglobulin light chain prototype Roy. Parentheses indicate amino acid residues not fully identified. 
For exact subtyping, this is at present a laborious method which demands immunoglobulin subtype specific antisera which are not available commercially. Surgical subcutaneous fat biopsy specimens for immunological typing of the amyloid are technically simple, rapidly performed, are without real risk and can be performed in almost any patient. A method for extracting amyloid fibrils for purification of fibril proteins and subsequent amino acid sequence analysis in live patients has, however, been lacking.

The present study shows that amyloid fibril proteins in systemic amyloidosis can be purified from a biopsy specimen of subcutaneous abdominal fat. At the time of writing, we applied the method to three further patients with AL-amyloidosis. In two of these patients an $\mathrm{N}$-terminal sequence of the subunit $\mathrm{AL}$-protein was obtained, permitting subtyping. In the third case the AL-protein had a blocked N-terminus. Because many of the patients with systemic AL-, AA-, and transthyretin-derived amyloidoses have moderate to large amounts of amyloid in the subcutaneous abdominal fat, ${ }^{6-11}$ this method should be useful in a significant portion of these severely ill patients. Almost all studies on amyloid fibril proteins have been performed on necropsy material. The simple subcutaneous fat biopsy specimen can be used with micromethods in the purification of proteins and modern ways of performing amino acid sequence analyses in the studies of many patients with systemic amyloidosis. A knowledge of the precise nature of the amyloid type and subtype may be of importance for the determination of prognosis and for the choice of treatment. ${ }^{20-22}$

This project was supported by the Swedish Medical Research Council (Project No. 5941), the Research Fund of King Gustaf V and the County Council of Östergötland.

\section{References}

1 Glenner GG, Terry W, Harada M, Isersky C, Page D. Amyloid fibril proteins: proof of homology with immunoglobulin light chains by sequence analysis. Science 1971;172:1150-1.

2 Benditt EP, Eriksen N, Hermodson MA, Ericsson LH. The major proteins of human and monkey amyloid substance: common properties including unusual $\mathrm{N}$-terminal amino acid sequences. FEBS Lett 1971;19:169-73.

3 Costa PP, Figueira AS, Bravo FR. Amyloid fibril protein related to prealbumin in familial amyloidotic polyneuropathy. Proc Natl Acad Sci USA 1978;75:4499-503.

4 Tawara S, Nakazato M, Kangawa L, Matsuo H, Araki S. Identification of amyloid prealbumin variant in familial amyloidotic polyneuropathy (Japanese type). Biochem Biophys Res Commun 1983;116:880-8.

5 Sletten K, Westermark P, Natvig JB. Senile cardiac amyloid is related to prealbumin. Scand J Immunol 1980;12:503-6.
6 Westermark P, Stenkvist B. A new method for the diagnosis of systemic amyloidosis. Arch Int Med 1973;132:522-3.

7 Stenkvist B, Westermark P, Wibell L. Simple method of diagnostic screening for amyloidosis. Ann Rheum Dis 1974;33:75-6.

8 Libbey CA, Skinner M, Cohen AS. Use of abdominal fat tissue aspirate in the diagnosis of systemic amyloidosis. Arch Int Med 1983;143:1549-52.

9 Orfila C, Giraud P, Modesto A, Suc J-M. Abdominal fat tissue aspirate in human amyloidosis: Light, electron and immunofluorescence microscopic studies. Hum Pathol 1986;17:366-9.

10 Maruyama K, Ikeda S, Yanagisawa N, Nakazato M. Diagnostic value of abdominal fat tissue aspirate in familial amyloid polyneuropathy. J Neurol Sci 1987;81:11-18.

11 Gertz MA, Li C-Y, Shirahama T, Kyle RA. The subcutaneous fat aspirate: a controlled and blinded evaluation of the technique in the diagnosis of primary amyloidosis (AL). In: Isobe T, Araki S, Uchino F, et al, eds. Amyloidosis. New York: Plenum, 1988: 801-5.

12 Westermark P, Stenkvist B, Natvig JB, Olding-Stenkvist E. Demonstration of protein AA in subcutaneous fat tissue obtained by fine needle biopsy. Ann Rheum Dis 1979;38:68-71.

13 Westermark P, Benson L, Olofsson B-O. Fine needle aspiration biopsy of abdominal subcutaneous fat tissue for the diagnosis and typing of amyloidosis. In: Glenner GG, Osserman EF, Benditt EP; Calkins E, Cohen AS, Zucker-Franklin D, eds. Amyloidosis. New York: Plenum, 1986:613-15.

14 Blobel G, Dobberstein B. Transfer of proteins across membranes. 1. Presence of proteolytically processed and non-processed nascent immunoglobulin light chains on membrane-bound ribosomes of murine myeloma. J Cell Biol 1975;67:835-51.

15 Westermark P, Sletten K, Natvig JB. Structure and antigenic behavior of kappa I-immunoglobulin light-chain amyloid proteins. Acta Pathol Microbiol Scand (C) 1981;89:199-203.

16 Cornwell III GG, Husby G, Westermark P, Natvig JB, Michaelsen $T$, Skogen B. Identification and characterization of different amyloid fibril proteins in tissue sections. Scand $J$ Immunol 1977;6:1071-80.

17 Linke RP, Nathrath WBJ. Immunochemical typing of amyloid from tissue biopsies. Acta Histochem 1980;25:89-93.

18 Shirahama T, Skinner M, Cohen AS. Immunocytochemical identification of amyloid in formalin-fixed paraffin sections. Histochemistry 1981;72:161-71.

19 Cornwell GG III, Thomas B, Kyle RA, Sletten K, Westermark P. Immunohistochemical typing of tissues from 100 patients with systemic amyloidosis. In: Isobe T, Araki S, Uchino F, et al, eds. Amyloidosis. New York: Plenum, 1988:179-84.

20 Kyle RA, Greipp PR, Garton JP, Gertz MA. Primary systemic amyloidosis (AL): a prospective randomized comparison of melphalan-prednisone vs. colchicine in 101 cases. Am J Med 1985;79:708-16.

21 Fielder K, Durie BGM. Primary amyloidosis associated with multiple myeloma. Predictors of successful therapy. Am J Med 1986;80:413-18.

22 Cohen AS, Rubinow A, Anderson JJ, Skinner M, Mason JH, Iibbey C, Kayne H. Survival of patients with primary (AL) amyloidosis. Colchicine-treated cases from 1976 to 1983 compared with cases seen in previous years (1961 to 1973). Am J Med 1987;82:1182-90.

23 Kabat EA, Wu TT, Bilofsky H, Reid-Miller M, Perry H, Gottesman KS. Sequences of proteins of immunological interest. Fourth ed. Bethesda, Maryland: National Institute of Health, 1987.

Requests for reprints to: Dr P Westermark, Department of Pathology, University of Linköping, S-58185 Linköping, Sweden. 